\title{
Focus on children murdered by parents in Italy: A sad reality
}

\author{
PIETRO FERRARA ${ }^{1,2}$, MASSIMO PETTOELLO-MANTOVANI ${ }^{3}$, FRANCESCO CAVALERI ${ }^{2}$, ROBERTA AU- \\ TUORI ${ }^{2}$, ANNAMARIA SBORDONE ${ }^{2}$, MARIA AMATO², IDA GIARDINO ${ }^{4}$, FRANCESCA IANNIELLO ${ }^{1}$, VA- \\ LERIA SANNICANDRO ${ }^{1}$, ANTONIO CHIARETTI ${ }^{1}$, ANTONIO RUGGIERO ${ }^{1}$, ALBERTO VERROTTI \\ ${ }^{1}$ Institute of Pediatrics, Catholic University Medical School, Rome, Italy \\ ${ }^{2}$ Service of Pediatrics, Campus Bio-Medico University Medical School, Rome, Italy \\ ${ }^{3}$ Institute of Pediatrics, University of Foggia, Istituto di Ricovero e Cura a Carattere Scientifico "Casa Sollievo", Foggia, Italy \\ ${ }^{4}$ Department of Clinical and Experimental Medicine, University of Foggia, Foggia, Italy \\ ${ }^{5}$ Department of Pediatrics, University of L'Aquila, L'Aquila, Italy
}

\author{
Corresponding Author: \\ Pietro Ferrara \\ Institute of Pediatrics \\ Catholic University Medical School \\ L.go Francesco Vito, 1 \\ 00168, Rome, Italy \\ Phone: +39.06 .30154348$ \\ Fax: +39.06 .3383211$ \\ E-mail: pietro.ferrara@unicatt.it p.ferrara@unicampus.it \\ ORCID 0000-0001-9449-3464
}

\section{ABSTRACT}

With a documented history of over a century, it is noted that child murders, perpetrated by their own parents, are an interesting and dramatic phenomenon in the Italian territory. There are three forms of child homicides: neonaticide, infanticide and filicide.

Thanks to several legal reports and studies, it is possible to draw the profile of the typical murderer: usually a young, Northern Italian woman, unemployed, in a conflicting relationship and suffering from psychiatric disorders. In most cases, the crime takes place at home. No particular method for committing the murder is preferred, but the death of the child can be due to different causes.

Precautionary measures should be taken: parents should never be left alone facing health or psychiat-ric problems, families should be helped and supported during difficult times, women should be well-informed and aware of their rights.

Key words: forensic science, neonaticide, infanticide, filicide, childhood, rights

\section{INTRODUCTION}

The murder of children by their parents can be divided into three forms: neonaticide, infanticide and filicide.

The term neonaticide refers to cases where homicide occurs immediately after birth.
Infanticide (from the Latin infantis cidim or caedium which means the killing of those who cannot talk yet) is, on the other hand, the killing of a child within the first year of life. Filicide occurs when the victim is over one year of age.

The legal definition currently in force in the Italian Criminal Code is provided by article 578, entitled "Infanticide in Conditions of Material and Moral Abandonment", which states: "The mother causing the death of her newborn immediately after childbirth, or of the fetus during childbirth, when the fact is determined by conditions of material and moral abandonment related to childbirth, is punished with imprisonment from four to twelve years". (1)

\section{THE SITUATION IN ITALY OVER THE LAST CENTURIES}

From 1880 to 1883,30 cases of child murder occurred annually, in Italy. From 1906 to 1911 , there were 47 cases each year. From 1950 to 1959 there were 75 cases per year. In the following ten years, there were 54 child murders per year. There was a rapid decline after 1978. This evidence could be linked to the law on voluntary termination of pregnancy. (2) About 500 infanticides have been perpe-trated since 1970 . (3) Between 2001 and 2008, there were 58 infanticides committed by mothers $(8.28$ infanticides per year) but the number declined ( 3 in 2010, 2 in 2011 and 2 in 2012) after the law on anonymous childbirth came into force, that allows the mother not to recognize the child and leave it in the hospital to ensure its care and legal protection. (4)

In contrast, there has been a sharp increase in the number of filicides in Italy over the past 15 years, with 379 cases in the whole period, and a peak in 2014 when 39 filicides took place, one every 10 days, $77 \%$ more than in 2013. The filicides of under 14s have increased, from 9 cases in 2013 to 24 in $2014(+166.7 \%) .61 .5 \%$ of filicides were committed by fathers, mostly of older children, and $38.5 \%$ by mothers, especially of children under 14 years of age. (5) In 2015, newspapers described 3 cases of infanticide. (6-8) There were 10 cases in 2016. (9-16) Until June 21st 2017 there were 7 cases. (17-23)

The highest number of filicides occurred in Northern Italy. Lombardia is the region where the highest number of filicides took place, accounting for $17.4 \%$ of all cases, followed by Emilia Romagna (10.4\%) and Lazio (10\%). (24)

It is assumed that ten thousand children have suffered serious injury or permanent harm in the last 40 years, at the hands of their mothers and fathers. Moreover, murderous parents usually choose rudi-mentary weapons and horrific scenes of crime, which heightens the chilling dramatization of these most unfortunate children's deaths. (3) 


\section{THE PROFILES OF THE MURDERER AND THE VICTIM AND OTHER DATA REGARDING THE CRIME}

The outline of the murderous mother is varied. A study conducted on more than 50 reports carried out from 1967 to 2003 on the entire Italian territory asserts that in most cases the parents' age was from 26 to 32 years. $56 \%$ of them were born in the North of Italy and 30\% in the South of Italy; $42 \%$ had dropped out of middle school and 25\% of elementary school. 19\% had completed their secondary ed-ucation and $3 \%$ had graduated. $61 \%$ were married, $14 \%$ single, $15 \%$ lived with their partners, and $9 \%$ were separated. They had a conflicting relationship with their partners in $33 \%$ of cases, a good rela-tionship in $28 \%$, and had an absent husband in $10 \% .58 \%$ were housewives, $8 \%$ employed in factories or unemployed, $5 \%$ of them were students or pensioners, $3 \%$ secretaries. In $62 \%$ of cases they came from middle class families and in $28 \%$ from middle-low class families. $52 \%$ only had one child, $33 \%$ had two children, $15 \%$ three or more children. (25)

In $74 \%$ of cases, at the time of the offense, the perpetrators already suffered from psychiatric disor-ders and received care at local health services (55\% depression, $11 \%$ psychosis, $8 \%$ dissociative syn-drome, etc.), while in $29 \%$ they had no disorder. In $69 \%$ of cases there were previous warning inci-dents, 35\% had clear signs of distress, and $25 \%$ had been admitted into psychiatric hospitals. A quar-ter of the women with psychiatric problems had tried committing suicide at least once, and 5\% had already tried to kill the future victim. So, with regard to the motive, the first cause is mental illness (61\%), followed by Medea syndrome (14\%). In the field of mental illness, we remember psychotic disorder (49\%), personality disorders $(17 \%)$, anxiety disorders $(25 \%)$, organic disorders $(7 \%)$, and mood disorders $(1 \%) .(2,25)$

At the time of the offense, the culprit is unable to understand and take action in $68 \%$ of cases, in $28 \%$ this ability is greatly diminished, while $14 \%$ of murderous parents are perfectly alert and conscious of what they are doing. It is important to underline this last statement, because in these cases, that is when the crime takes place in the absence of an impairment of the ability to understand and take ac-tion, the law considers imprisonment. (2) After the murder, the convicted person commits suicide (23\%), immediately confesses the crime (21\%), or conceals the corpse $(10 \%) .(2,25)$ After the sentence of mental illness, in- ability to understand and take action, and social danger, hospi-talization in a psychiatric court is considered for $56 \%$ of cases; in $13 \%$ there is detention in prison; in $6 \%$ of cases, community or psychiatric hospitalization occurs. $(2,25)$

The victims are males in $53 \%$ of cases, females in $47 \%$, younger than one month of age in $16 \%$ of cases, between one month and one year in $20 \%$, and between 2 and 6 years in $36 \%$. In $89 \%$ of cases the victims did not exhibit any physical or mental illness. $(2,25)$

The type of crime involved in filicide can differ: the murder or the attempted murder of just one child occurs, in $61 \%$ and $24 \%$ of cases, respectively. In $6 \%$ of cases there are more victims. The crime takes place at home more often than outdoors $(85 \%$ vs $11 \%)$. At home, homicide occurs more frequently in the bathroom (64\%), in the bedroom (20\%) and rarely in the dining room (13\%). No particular way to commit the murder is preferred: homicide is committed with drowning (19\%), suffocation (18\%), puncture and cutting (15\%), with defenestration (15\%), with strangulation (10\%) or using a firearm (4\%). (2)

\section{THE CAUSES OF DEATH}

The death of the fetus or of the infant may occur naturally in relation to non-criminal causes, such as pre-maturity, congenital disease, and umbilical haemorrhage. During delivery, the infanticide of the baby is not so frequent but, it is possible and it can be due to cranial contusion, perforation of the fon-tanelles or airway obstruction. (26) The main causes of death of a newborn child carried out by parents are:

- skull fracture, caused, for instance, by blows against a wall or ceiling;

- suffocation with hands, with pillows, with excessively tight hugs, by locking in crates or trunks and rarely burying the child when he/she is still alive;

- strangulation using hands or a rope, but even using the umbilical cord of the infant;

- drowning;

- wounds: generally caused by cutting tools aimed at mutilation to facilitate the concealment of the remains;

- burns: fire is frequently used to hide the corpse;

- poisoning by sponges soaked in toxic substances;

- lack of care to keep the baby alive (e.g. by food deprivation);

The parent can cause the death of two or more children (enlarged homicide) with gas asphyxiation, stabbing, drowning, or shooting with firearms. (27)

\section{CLASSIFICATIONS}

In 1969, Resnick already proposed an interesting classification of filicide. (28) As a result of a study carried out from 1951 to 1967, he highlighted five categories of filicide and underlined that minors at higher risk are those up to six months of life. The aforementioned 5 categories identified by the author are the following:

1. "Altruistic filicide" is when the mother kills her child with the intention of saving him or her from a pre-existing illness and then commits suicide ("extended suicide").

2. "Highly psychotic filicide" occurs when a parent kills his or her child during imperative command hallucinations.

3. "Unwanted child filicide" occurs when the child is seen as the result of an extramarital relationship or because the mother is immature and adolescent or close to menopause. Suicide attempts are un-common in this case.

4. "Accidental filicide" occurs when the mother causes the child's death in an impulsive gesture due to frequent crying and screaming of the baby, even though she is generally not prone to violence. These mothers are often affected by personality disorders, irritability, and impulsive behaviour. They often suffered abuse in early life; the husband is also often disinterested in the problems of his wife.

5. Lastly, there is "filicide due to revenge on the spouse".

Nivoli (29) presents another classification:

1. Filicide caused by passive and negligent mothers occurs when the mother, especially if she is young, does not adequately care for the child's needs (nourishment, clothing suitable for temperature, protection, and medical care). They see their child as a threat for their own well-being, or as somewhat intrusive. The death of the child is caused by passive and omissive behavior.

2. Mothers who kill their children because of their frustrations. They are mothers who believe that the child is the cause of a ruinous existence. They perceive that the child has "re-shaped" their body through pregnancy, conditioned them to live in an unpleasant environment or with a com-panion they do not love or do not live happily with, forced them to spend the whole day taking care of his or her needs or whims. 
3. Mothers who deny the pregnancy and consider the neonate as faeces. These are mothers who de-ny, in a hysterical way, their pregnancy, dressing in such a way as to conceal that they are preg-nant without requesting medical treatment during gestation or at birth, which is then performed in solitude. In the immediacy of childbirth, they kill or abandon their baby (in dumps, public toilets, etc.).

4. Mothers who misplace the desire to kill their own mothers onto their child. There is therefore an introjection of the desire to kill their own bad mothers, and only secondarily the shift of this aggression towards their child.

Thanks to the observation of more than 500 psycho-biographies, (30) infanticide mothers can be sub-divided according to motive and/or psychopathology into 20 categories, divided between women able to understand and take action and those who have a totally or partially altered ability to understand and take action.

When the filicide is caused by women capable of understanding and taking action, the motives are: life stressor events, pietas (altruistic murder), the mother's immaturity, the fact that the child is hyperac-tive, the fact that the child is perceived as the result of a sinful act, Medea syndrome, personality dis-orders (addicted, narcissistic or histrionic), the fact that the child is unwanted, depression in a narcis-sistic subject, and behavioral disorders due to alcohol and drug abuse. (30,31-34) If pathological causes with partial (greatly diminished) or total impairment to understand and take action are present, the motives are: postpartum psychosis, hysteric fundus, major depression, schizophrenia, twilight state, psychotic disorder due to a general medical condition, epilepsy, oligophfrenia, plaque sclerosis, and multiple personality. (30)

\section{CONCLUSION}

Even though filicide occurs in different scenarios, for different reasons, both by the mother and by the father, a profile of the perpetrator of the infanticide can be traced. This is often a young woman aged between 18 and 32 years, of Italian nationality and with an average level of schooling; married but in a problematic and/or conflicting relationship with the partner; a housewife, often not as a result of her inclinations but generally to please her husband/partner. She executes the crime in her home, especial-ly in the bathroom and in the bedroom, usually on children under the age of 7; she uses "immediate" modes to commit the crime, such as drowning, suffocating, defenestration. The main motive is mental illness; in fact, after the crime, the perpetrator is often found in confusion at the crime scene, she con-fesses or attempts suicide; she has shown signs of psychological distress in the past (attempted sui-cide, psychiatric hospitalization, and in some cases attempted murder of the future victim). (25)

Measures to prevent the murder of these children should be undertaken.

For instance, 40 "cradles of life" are spread over the Italian territory; these being a legacy of the old "wheel of life" in convents and monasteries where infants were once left. They generally remain emp-ty. To limit the number of infanticides and neonaticides, women should be better informed of this ser-vice, anonymous and free, but potentially life-saving. Women should also be aware of their rights, as the one of being able to give birth anonymously. However, there are still very few women making use of such a possibility. (35)

Precautionary measures should also be taken during separation and divorce. Couples arriving at court should have free access to psychotherapy or family mediation paths to really understand what the psy-chologi$\mathrm{cal}$ and legal consequences of divorce may be. Believing that a legal suit of separation is only a matter of law is quite irresponsible, assessing the level of hatred that may arise in a couple that is dis-integrating. We need a procedural reform of family law and, above all, an awareness campaign to make sure that children's rights have a priority over all others. $(3,36,37)$

Since in most cases women are the perpetrators of infanticide, and as most of them suffer from psy-chiatric illnesses, experts suggest that "we need to intercept mothers" before the irreparable happens. Not only social workers, but everyone who is, for any reason, in close contact with mothers and fa-thers, should be able to recognise any warning signs and give support.

\section{REFERENCES}

1. Di Blasio MP. L'infanticidio nella legislazione penale:uno sguardo al passato per capire il presen-te.Giurisprudenza Penale [Online] 2016 [cited 2016 March 23]; Available from: URL: http://www.giurisprudenzapenale.com/2016/03/23/linfanticidio-nella-legislazione-penale-uno-sguardo-al-passato-capire-presente/

2. Mastronardi V, De Vita L, Umani Ronchi F. Some Italian research on the phenomenon of filicide. Riv Psichiatr 2012;47(4 ):11-6.

3. Associazione Avvocati Matrimonialisti Italiani. Madri che uccidono - Stop allinfanticidio 500 ca-si di morte violenta dal 1970 ad oggi.Urgono misure anti infanticidio [Online] 2014 [cited 2017 Jul 23]; Available from: URL: https://www.ami-avvocati.it/madriche-uccidono-stop-allinfanticidio-500-casi-di-morte-violenta-dal-1970-ad-oggi-urgono-misure-anti-infanticidio/

4. Il Corriere della Sera. Ma i dati dicono che oggi le mamme uccidono di meno [Online] 2014 [cited 2017 Jul 23]; Available from: URL: http://27esimaora.corriere.it/articolo/mai-dati-dicono-che-oggi-le-mamme-uccidono-di-meno/

5. Ansa.Un figlicidio ogni 10 giorni [Online] 2015 [cited 2017 Jul 23]; Available from: URL:http://www.ansa.it/sito/notizie/cronaca/2015/10/12/un-figlicidio-ogni-10-giorni_6ebd9372-4dd6-4242-815f-2442ae7b0aef.html

6. Il mattino di Padova. Nata viva di 7 mesi e uccisa a coltellate: l'autopsia conferma, è infanticidio [Online] 2015 [cited 2017 Jul 23]; Available from: URL:http://mattinopadova.gelocal.it/padova/cronaca/2015/11/28/news/la-bambina-era-nata-viva-poi-e-statapresa-a-coltellate-1.12524148

7. Corriere. Uccide moglie e figlia di sette anni con un'accetta dopo l'ennesima lite [Online] 2015 [ci-ted 2017 Jul 23]; Available from: URL:http://www.corriere.it/cronache/15_aprile_15/uccide-moglie-figlia-7-anni-un-accetta-83438d5c-e32b-11e4-8e3e-4cd376ffaba3.shtml

8. Corriere del Veneto. Ammazza la figlia di 21 anni con un colpo di pistola e poi si uccide [Online] 2015 [cited 2017 Jul 23 ]; Available from: URL:http://corrieredelveneto.corriere.it/veneto/notizie/cronaca/2015/5-ottobre-2015/ammazza-figlia-21-anni-un-colpopistola-poi-si-uccide--2302011162465.shtml

9. Corriere. Perugia, padre uccide i figli e si suicida «Non provate a fermarmi» [Online] 2016 [cited 2017 Jul 23]; Available from: 
URL:http://www.corriere.it/cronache/16_gennaio_30/perugia-padre-uccide-figli-13-8-anni-si-suicida-3580703c-c749-11e5-b16b305158216b61.shtml

10. Giornale di Sicilia. Bimbe uccise a Gela, la madre in carcere. Il marito: litigavamo, non l'avrei la-sciata [Online] 2016 Dic 28 [cited 2017 Jul 23]; Available from: URL:http://caltanissetta.gds.it/2016/12/28/bimbe-uccise-a-gela-la-madre-in-carcere-il-marito-litigavamo-ma-non-lavrei-lasciata_609179/

11. Ansa. Bimbo morto in armadio, ucciso da madre [Online] 2016 [cited 2017 Jul 23]; Available from: URL:http://www.ansa.it/piemonte/notizie/2016/10/25/bimbo-morto-in-armadio-ucciso-da-madre_7f3ec58e-28e9-43f4-bd5d-5419dd480be8.html

12. Ansa. Soffoca figlia di 3 mesi in culla ospedale, arrestato [Online] 2016 [cited 2017 Jul 23]; Avai-lable from: URL:http://www.ansa.it/ puglia/notizie/2016/11/10/ansa-soffoca-figlia-di-3-mesi-in-culla-ospedale-arrestato_44cebdf5-bed4-47a7-aa66-53e67f80aa2e.html

13. Ansa. Taranto, uccide moglie e figlio e poi si suicida [Online] 2016 [cited 2017 Jul 23]; Available from: URL:http://www.ansa.it/puglia/notizie/2016/06/07/taranto-uccide-moglie-figlio-e-poi-si-suicida_de35d966-0647-440b-bc9d-4b7f7f04d46d.html

14. Ansa. Mamma e piccolo morti: piccolo strangolato [Online] 2016 [cited 2017 Jul 23]; Available from: URL:http://www.ansa.it/sito/ notizie/cronaca/2016/05/25/mamma-e-bimbo-morti-piccolo-strangolato_566dd890-c9d7-417b-8787-a34c47ad5a3b.html

15. Ansa. Scoperti due cadaveri carbonizzati nel Salernitano [Online] 2016 [cited 2017 Jul 23]; Avai-lable from: URL:http://www.ansa. it/sito/notizie/cronaca/2016/03/31/-scoperti-due-cadaveri-carbonizzati-nel-salernitano_7c74ea45-3d49-41f9-bbe6-49246919ed79. html

16. Ansa. Macerata, è omicidio-suicidio: madre uccide il figlio e poi si spara [Online] 2016 [cited 2017 Jul 23]; Available from: URL:http://www.ansa.it/marche/notizie/2016/02/13/macerata-madre-e-bambina-uccise-a-colpi-di-arma-da-fuoco_e7bba73522cd-47d7-a084-05d98d872fc3.html

17. Il gazzettino. Torino, mamma accoltella il figlio di 7 anni e si uccide lanciandosi dal balcone [Onli-ne] 2017 [cited 2017 Jul 23]; Available from: URL:http://www.ilgazzettino.it/italia/cronaca_nera/torino_mamma_accoltella_figlio_uccide_balcone-2254764.html

18. Corriere della sera. Partorisce e nasconde neonato in freezer [Online] 2017 [cited 2017 Jul 23]; Available from: URL:http://www.corriere.it/notizie-ultima-ora/Cronache/Partorisce-nasconde-neonato-freezer/09-06-2017/1-A_045762057.shtml

19. Today. Neonato abbandonato nel torinese, la madre aveva nascosto a tutti la gravidanza [Online] 2017 [cited 2017 Jul 23 ]; Available from: URL:http://www.today.it/citta/valentina-ventura-neonato-abbandonato-settimo-torinese.html

20. Il Fatto Quotidiano. Trento, padre uccide i figli a martellate. L'sms ai nonni: "Hanno dormito male, non venire". I debiti nascosti alla famiglia [Online] 2017 [cited 2017 Jul 23]; Available from: URL:http://www.ilfattoquotidiano.it/2017/03/29/trento-padre-uccide-ifigli-a-martellate-lsms-ai-nonni-hanno-dormito-male-non-passare-i-debiti-nascosti-alla-famiglia/3483747/

21. La Repubblica. Padula, si lancia dal balcone con il figlio di tre anni: muoiono entrambi Online] 2017 [cited 2017 Jul 23]; Available from: URL:http://napoli.repubblica.it/cronaca/2017/01/24/news/padula_si_lancia_dal_balcone_con_il_figlio_di_tre_anni_muoiono_entrambi-156740326/

22. Ansa. Nasconde feto nell'armadio, 17enne indagata per infanticidio [Online] 2017 [cited 2017 Jul 23]; Available from: URL:http:// www.ansa.it/puglia/notizie/2017/02/10/nasconde-feto-nellarmadio-indagini-cc_663a4a0a-cf4d-4d1b-9bb1-8d0f93acc510.html

23. Ansa. Bimbo morto, madre ammette, lo picchiai [Online] 2017 [cited 2017 Jul 23]; Available from: URL:http://www.ansa.it/emiliaromagna/notizie/2017/02/17/bimbo-morto-madre-ammette-lo-picchiai_a37a05ce-3530-46de-9987-c2958d23cd1b.html

24. Bambara E. Figlio mio ti uccido. In Terris, Online International Newspaper [Online] 2015 Oct 21 [cited 2017 Jul 23]; http://www. interris.it/2015/10/21/75949/posizione-in-primo-piano/schiaffog/figlio-mio-ti-uccido.html

25. Bramante A, Merzagora Betsos I. Psichiatria, cultura, figlicidio. Interazioni-psichiatria-giustizia. Atti del Convegno, Aversa, 2004.

26. De Paula Rodrigues V. Infanticidio e a morte culposa do recémnascido. Campinas: Millennium Editora; 2004.

27. Gomes H. Medicina legal rev. e ampl. por Equipe Coordenada pelo Prof. Huggino de C. Hercu-les. 32th ed. Rio de Janeiro: Freitas Bastos; 1997.

28. Resnick PJ. Child murder by parents: a psychiatric review of filicide. Am J Psychiat 1969 Sep;126(3):325-34.

29. Nivoli GC. Medea tra noi. Le madri che uccidono il proprio figlio. Roma: Carocci; 2002.

30. Mastronardi V, Villanova M. Madri che uccidono. Le voci agghiaccianti e disperate di oltre tre-cento donne che hanno assassinato i loro figli. Roma: Newton Compton; 2007.

31. Ferrara P, Caporale O, Cutrona C, Sbordone A, Amato M, Spina G, et al. Femicide and murdered women's children: which future for these children orphans of a living parent? Ital J Pediatr 2015 Sep 29;41(1):68.

32. Ferrara P, Vena F, Caporale O, Del Volgo V, Liberatore P, Chiaretti A, et all. Children left unat-tended in parked vehicles: a focus on recent italian cases and a review of literature. Ital J Pediatr 2013 Nov 6;39(1):71.

33. Ferrara P, Ianniello F, Cutrona C, Quintarelli F, Vena F, Del Volgo V, et all. A focus on recent cases of suicides among Italian children and adolescents and a review of literature. Ital J Pediatr 2014;40:69.

34. Ferrara P, Romani L, Bottaro G, Ianniello F, Fabrizio GC, Chiaretti A, et all. The physical and mental health of children in foster care. Iran J Public Health 2013;42(4):368-73.

35. Bresciaoggi. Dietro l'infanticidio il male del nostro tempo. [Online]. 2013 [cited 2017 Jul 23]; Available from: URL:http://www. bresciaoggi.it/home/italia-mondo/dietro-l-infanticidio-il-male-del-nostro-tempo-1.4194468

36. Corsello G, Ferrara P, Chiamenti G, Nigri L, Campanozzi A, Pettoello-Mantovani M. The child health care system in Italy. J Pediatr 2016 Oct;177S:116-26.

37. Ferrara P, Corsello G, Basile MC, Nigri L, Campanozzi A, Ehrich J, et all. The economic burden of child maltreatment in high income countries. J Ped 2015;167(6):1457-9. 